\title{
A case study: assessing the impacts of open cut coal mining on the Maryvale Field (Yallourn) Open Cut and Morwell River Diversion through the use of finite element modelling
}

\author{
S Narendranathan GHD Pty Ltd, Australia \\ J Stipcevich GHD Pty Ltd, Australia \\ S Rastogi EnergyAustralia Pty Ltd, Australia
}

\begin{abstract}
EnergyAustralia Pty Ltd-the current owners and operators of the Yallourn Open Cut coal mine-are planning to progress mining development into the Maryvale Field (MVF). Morwell River is located adjacent to the Western Batters of the MVF mine development. The upstream section is a meandering river channel with some realignments associated with mining in the adjacent Township Field (YTF), while the downstream section is an engineered Morwell River Diversion (MRD). A buffer zone between Western Batters and the Morwell River varies in width along Western Batters. The planned development at the MVF site poses some unique challenges in terms of slope stability and potential ground movement as mining activities progress. This paper presents a case study on the calibration and use of finite element models (FEMs) to assess the impacts of open cut mining activities on potential ground movement and slope stability of the MVF open cut mine and neighbouring natural Morwell River Channel and MRD.
\end{abstract}

Keywords: slope stability, ground movement, open cut mining, brown coal, finite element modelling, model calibration

\section{Introduction}

\subsection{Overview}

The Maryvale Field (MVF) open cut, otherwise known as the Yallourn Open Cut, and the Yallourn W Power Station are located approximately $150 \mathrm{~km}$ east of Melbourne in the Latrobe Valley region of Victoria, Australia. Coal mining and power generation at the site commenced in the 1920s with the establishment of Yallourn Coal Mine and commissioning of the first in a series, the Yallourn A Power Station. EnergyAustralia Yallourn (EAY) are the current operators of Yallourn Open Cut and intend to progress mining in MVF until the planned cessation of mining 2032.

The Morwell River Diversion (MRD) that runs adjacent to the MVF Western Batters is separated from the mine batter crest by a buffer zone. At the closest point, the mine batter crest is $300 \mathrm{~m}$ from Morwell River low flow channel and $330 \mathrm{~m}$ at RL $43 \mathrm{~m}$ AHD flood level from the Morwell River floodplain. This essentially represents a 'stand-off' (buffer) zone that separates the mines Western Batters from Morwell River and MRD floodplain. The intention of this paper is to outline the approach by which a calibrated finite element model (FEM) was utilised to verify the adequacy of the 'buffer zone' for mitigating the risk of potential instability. The processes by which geotechnical monitoring information was reduced and correlated with mine development and subsequently incorporated into a calibrated FEM will be outlined. This paper will also discuss the process by which the calibrated FEM was successfully used in a predictive capacity to determine the efficacy of the current mine design in the light of the remaining planned stages of mine development interacting with the buffer zone. 


\subsection{Background}

The subject feature of this paper-the buffer zone between the Morwell River MRD and the MVF open cut -has been subjected to various episodes of loading and unloading (extensional strain) over an extended course of mining. The area to the west of the current mine was mined several decades ago and subsequently backfilled with overburden (Yallourn Township Field, YTF - Midfield Dump) (Figure 1).

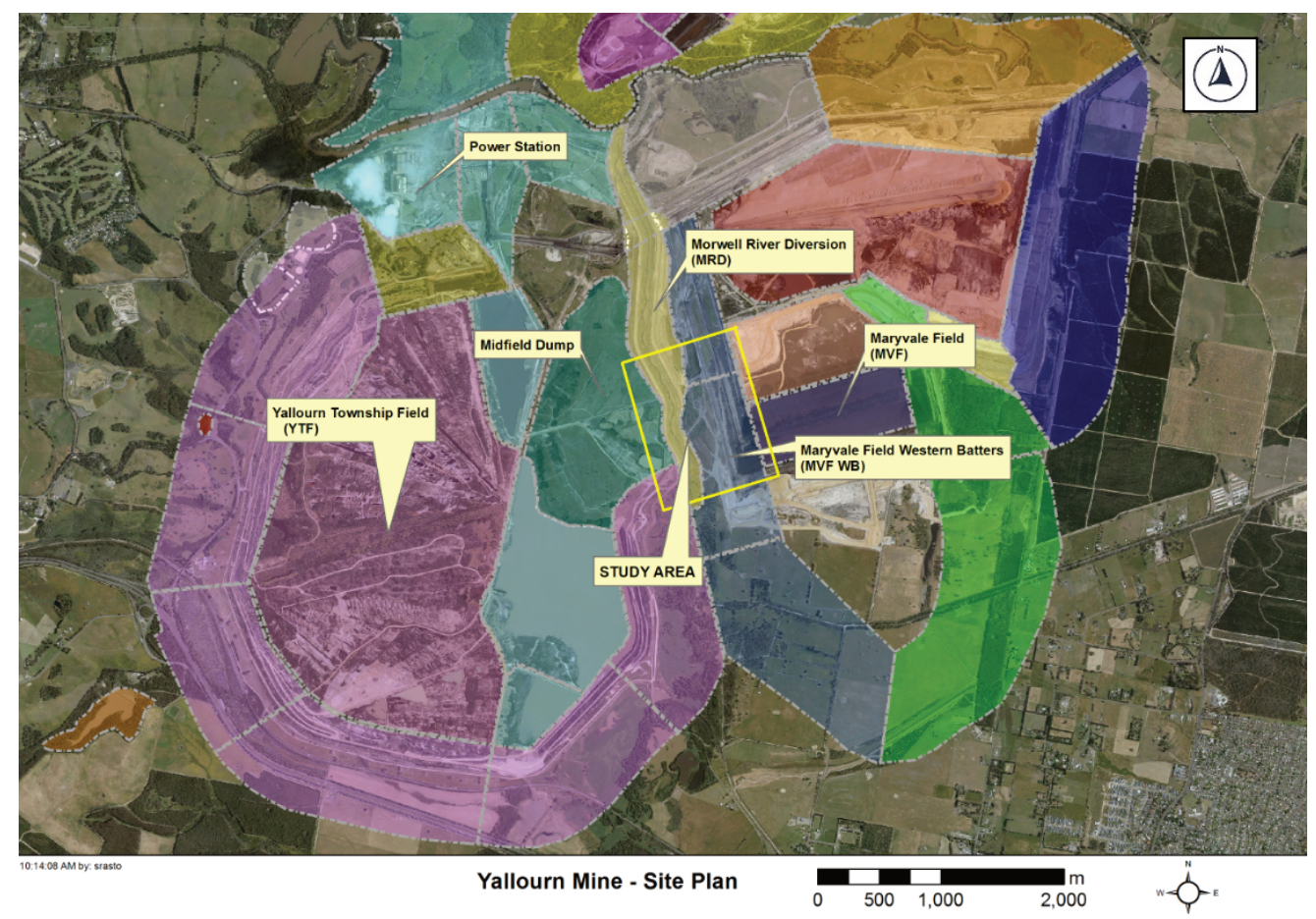

Figure 1 Site plan of the Yallourn (Maryvale Field) open cut depicting case study area

On 14 November 2007, a large-scale slope failure occurred on the North Batters within the Yallourn east field that extended back to the neighbouring Latrobe River. This occurrence resulted in the mobilisation of approximately $6,000,000 \mathrm{~m}^{3}$ of material (Figure 2) and affected a significant area of ground, and demonstrates what could happen in a 'worst case' scenario. Additional information on this can be found in the Mining Wardens report 'Yallourn Mine Batter Failure Enquiry' (Government of Victoria 2008).

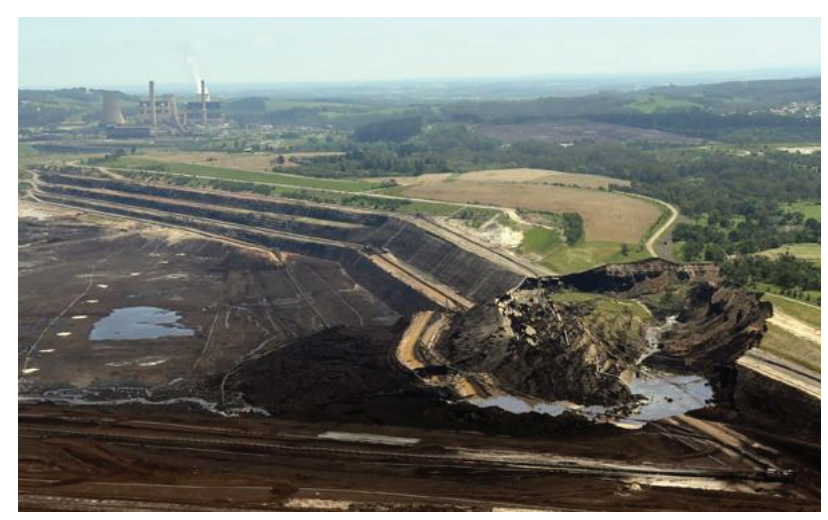

Figure 2 Failure of the Yallourn east field northern batters 2007

In addition to backfilling of the YTF midfield dump and overburden stripping in MVF, surcharges have been constructed in the buffer area to enhance the overall stability of Western Batters. These instances of loading (surcharging) and unloading (overburden stripping) upon the area at, and in proximity to, the buffer would have induced a number of 'episodes' of strain and stress relief upon it, compounded by the effects of mine dewatering. Accordingly, it should be appreciated that the future response of the buffer zone, which is in a 
stress-relieved 'halo' may be dissimilar to that of 'undisturbed ground'. These constitute challenges that need to be considered when formulating a calibrated FEM.

As part of geotechnical risk management process, EAY has developed and implemented a robust geotechnical and hydrogeological database which had captured much of the ground response to a number of these 'episodes'. Shown below in Figure 3 is the installed network of ground movement monitoring equipment in the buffer zone which is comprised of inclinometers, extensometers and survey pins/pillars. The monitoring network was enhanced in 2012 with additional monitoring devices installed commensurate with the development of mining. The original buffer zone design was subjected to cursory FEM modelling (2008) which incorporated assumptions in relation to stiffness parameters, i.e. Young's modulus (E), shear modulus (G), Poison's ratio (v) and in situ stress conditions. Since 2011, mine development has progressed along the Western Batters of the mine, which provided an excellent opportunity to observe and record the ground response to mining. Discussed subsequently in this paper will be an overview of the mine development activities between 2008 and early 2019, and the outcomes of deformation/movement monitoring outcomes during this period, which formed a crucial input into the FEM calibration process.

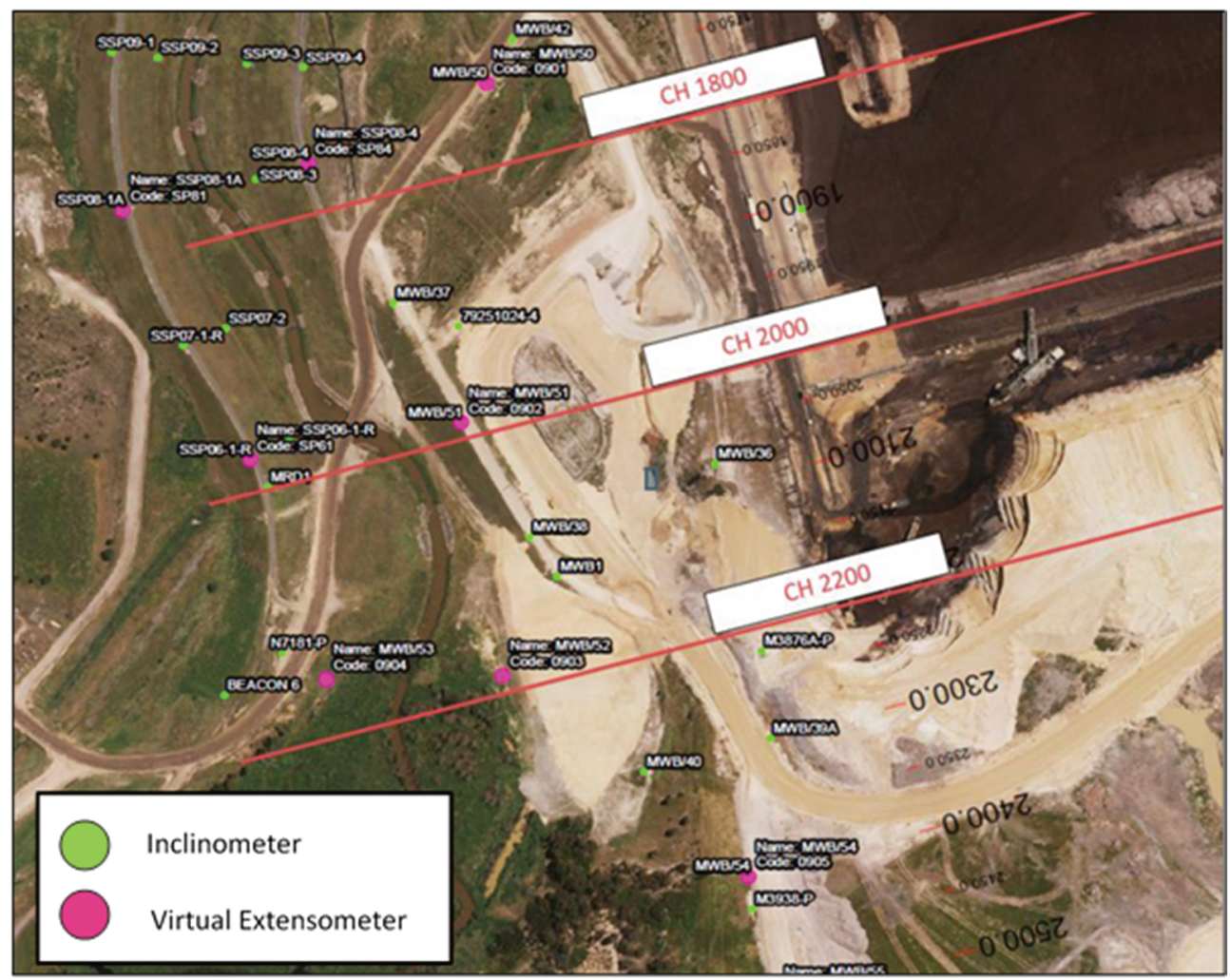

Figure 3 Maryvale Field-Morwell River Diversion monitoring network

\section{Considerations when constructing a calibrated finite element models at the Yallourn Mine}

\subsection{Mine batter stability and finite element models}

The stability of brown coal open cut batters in the Latrobe Valley region of Victoria present some unique challenges as brown coal is 'light' with a specific gravity of 1.1 which is slightly higher than water, the strength of the geological units can be variable and disparate from each other, and it tends to exhibit both brittle and ductile behaviour. Owing to the above, the slopes are typically controlled by two instability modes, which are block sliding (primary mode) and tetrahedral wedge sliding (secondary mode). Tetrahedral wedges typically manifest as a result of intersecting joint structures, which typically are randomly orientated. Subsequently, wedge formations tend to be of low volume/scale, occurring usually at the bench (local) scale. Coal block sliding, 
on the other hand, tends to occur at the overall slope (global) scale. Historically, block sliding instabilities within the Latrobe Valley have eventuated as the result of excess water pressure build-up in the dominant sub-vertical coal joint overcoming the resistance within the underlying, weaker interseam (clay) layers.

The Western Batters at the MVF have a pre-existing deformation history induced by past mining activities within the Township Field area adjacent to the MVF batters being investigated as previously outlined. In the absence of historic data, it was necessary to implicitly calibrate the FEM model with considerations made to the material stiffness parameters, i.e. Young's modulus and Poisson's ratio, for each of the geological units as well as the in situ lithostatic (field stress) conditions.

As phreatic conditions within the coal and the interseam layer are crucial considerations in the initiation of the block sliding mechanism, a robust FEM will need to ensure appropriate 'coupling' of the geotechnical and hydrogeological models. Water pressures within coal are closely monitored by the mine and are maintained at 'stable' levels using passive (sub-horizontal drainholes) dewatering methods and active dewatering bores for the deeper aquifers.

Excavation of coal in combination with dewatering processes cause slope and ground deformation as a result of relaxation. For recently developed areas of the mine, deformation of coal batters due to relaxation can occur over extended periods and greater extents of development, ongoing creep deformation of coal batters may lead to crack initiation, dilation and propagation, and ultimately the opening of large sub-vertical joints (extensional fractures). Surface water ingress into the naturally formed vertical joints leads to increase in pore pressure build-up, which essentially acts as a hydrostatic driving head for the block sliding mechanism as shown in Figure 4 (Narendranathan \& Cheng 2019).

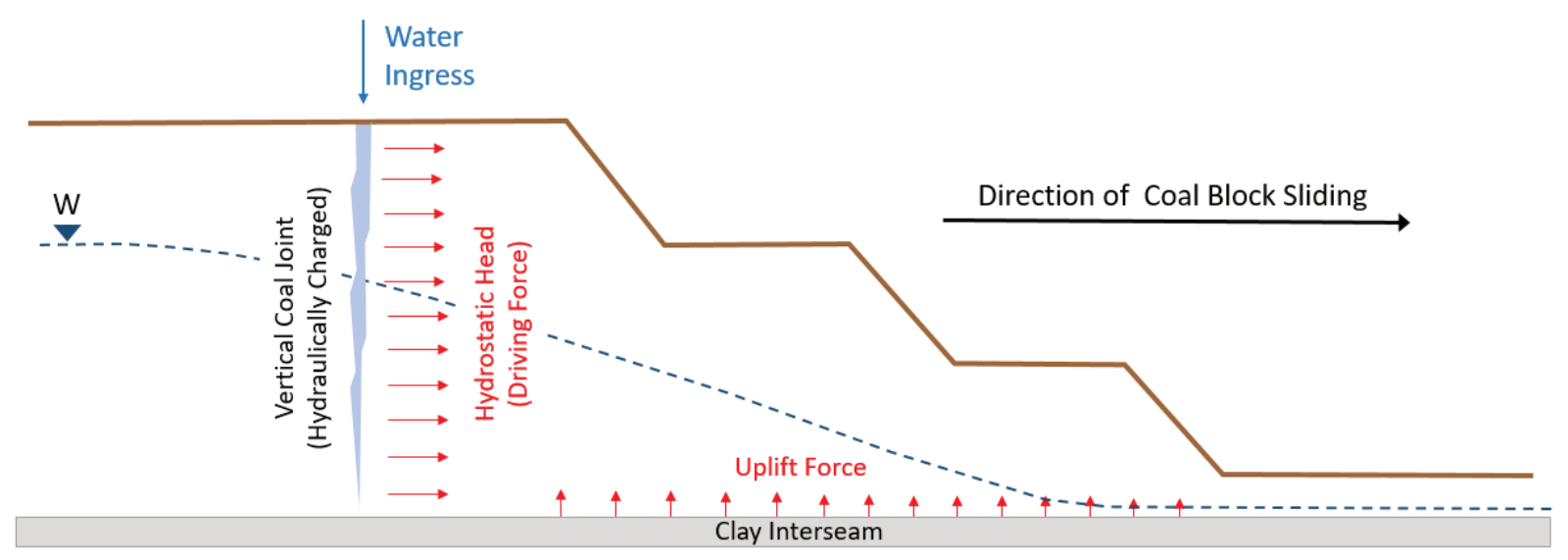

Figure 4 Block sliding mechanism

Given the proximity of the Morwell River and MRD to the MVF Western Batters, deformations that result in excessive cracking pose a risk to the overall slope stability, i.e. a breach of the Morwell River and MRD channels causing water inflow directly into large vertical cracks will result in unfavourable hydrostatic conditions. The extent of deformation that would lead to the formation of large vertical joints along the Morwell River, MRD and buffer zone can be challenging to measure and model. At the Yallourn mine, tolerable deformations are typically attributed in the form of cumulative horizontal/vertical displacements in conjunction with displacement rate/s and or strains. Accordingly, these metrics need to be considered and suitably incorporated into the FEMs with the benefit of appropriate calibration.

Calibration of FEM models can be considered as the verification and validation procedure in which the efficacy of the model is substantiated through a positive comparison to test data (Abrahamsson \& Kammer 2015). Field monitoring data used to measure deformations at the Yallourn mine is typically done using, survey pins, inclinometers, extensometers and GPS survey pillars or a combination of these. Using initial deformation estimates, FEM models can be iteratively calibrated until the modelled deformation is representative of the actual measured magnitudes, and a set of calibrated material stiffness parameters can 
be obtained for the geological units of interest. Once calibrated, FEM models can be used to predict expected deformations that result from further mining.

\subsection{Investigation approach}

The approach applied in formulating the ground movement model for the Yallourn mine is as follows:

- Critical stability sections were identified for the purposes of evaluating the mining-induced deformations within the MVF Western Batters, the Morwell River, MRD and associated buffer zone.

- Identification of specific field monitoring data sources (pins, survey pillars, inclinometers, extensometers and piezometers) for the purposes of model calibration that are coincident with the nominated stability sections.

- Subsequent to field monitoring test data collection, develop a data reduction and interpretation philosophy to define the spatial extents of spatial deformation of the respective geological units and digitisation of the mine batter geometry within the identified stability sections:

○ Interpretation of the structural (joint) orientations.

○ Persistence within the coal seam/s.

- Evaluation of encountering other geological features within the subject sections.

- Upon the digitisation of the model, formulating a suitable mesh discretisation algorithm to ensure suitable mesh quality to facilitate calculation of deformation in critical areas.

- Iteratively calibrating the FEM (ground movement) model with the observed slope deformation/ performance outcomes to the respective (past) stages of mine development.

- The calibration process implicitly considered current and past phases of cracking/defects and past mining activities.

- Prediction of deformations and strains for the mine batters, Morwell River, MRD and buffer zone using the calibrated model to assess the performance adequacy of the buffer zone.

\section{Case study: Maryvale Field-Morwell River Diversion buffer and associated batters}

\subsection{Background and introduction to subject site}

The advancement of mine operations at the Yallourn Open Cut is progressing in a southerly direction along the Western Batters of the MVF mine. The maximum depth of the MVF pit at final development is in the order of $150 \mathrm{~m}$. Critical sections across $500 \mathrm{~m}$ of the MVF Western Batters were identified based upon minimum stand-off distances to the MRD as depicted in Figure 5.

\subsection{Development geometry of the MVF batters}

Typically, permanent batters are formed at an angle of $45^{\circ}$ using 'dozer push' techniques. Sloped coal faces along the Western Batters are currently in the order of 40 to $50 \mathrm{~m}$ in height, with a 40 to $50 \mathrm{~m}$ wide bench separating the upper and lower batters. As a result of design/operational practicalities, some variability in the form of 'transitionary' wider bench configurations (up to $90 \mathrm{~m}$ ) and steeper batters are currently present. A coal strut approximately $15 \mathrm{~m}$ thick is located at the toe of the mine's Western Batter (floor) to provide supplementary support to the batters above, effectively acting as a buttress (Figure 6). 


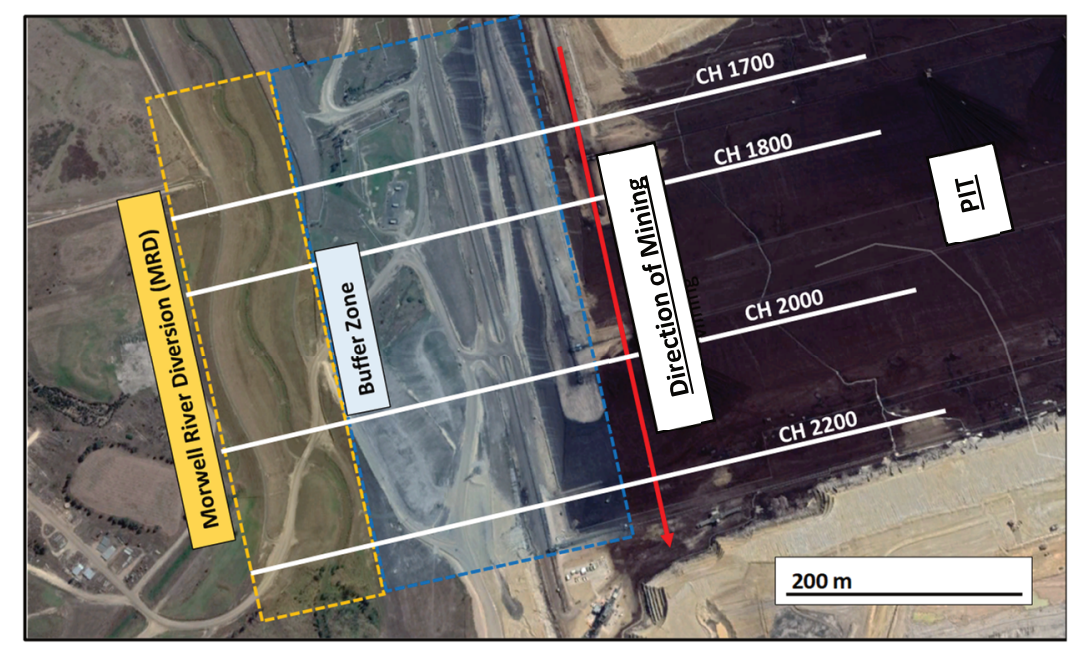

Figure 5 Plan view of the Maryvale Field open cut depicting Morwell River Diversion, buffer zone, pit and direction of mining

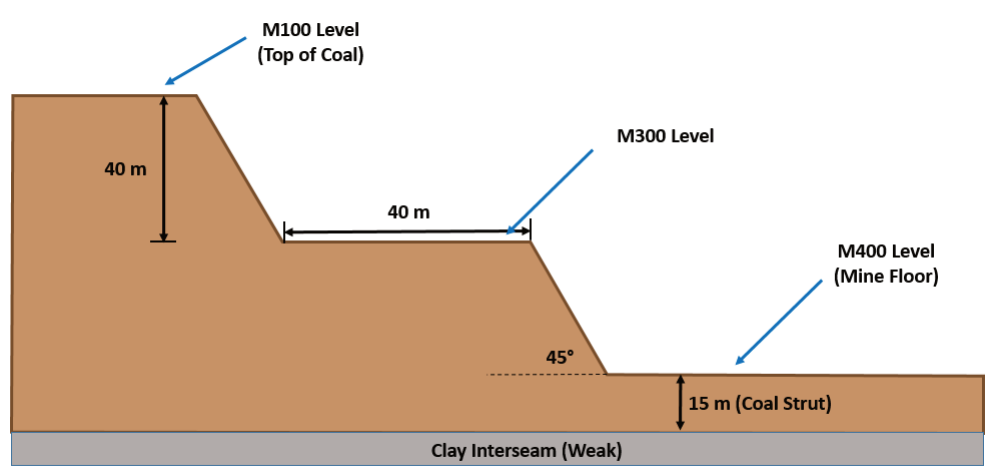

Figure 6 Typical slope geometry at Yallourn Open Cut

\subsection{Identification of critical stability sections}

Four sections along the Western Batters were identified for ground movement modelling (Figure 5). The stability sections are considered to be the most critical in terms of stand-off distance between the Morwell River and MRD and mine crest. It is reasonable to expect that at these sections there would be a higher impact of deformation/movement compared to other sections of the Morwell River and MRD due to their closer proximity to mine batters. The stand-off distance between each of the stability lines is summarised below in Table 1, and represent the least 'stand-off' distances to the mine void across its alignment.

Table 1 Stand-off distances to edge of flooding plain (RL $43 \mathrm{~m}$ AHD) for stability sections

\begin{tabular}{ll}
\hline Stability section & Stand of distance \\
\hline MVCh1700 & 350 \\
MVCh1800 & 380 \\
MVCh2000 & 320 \\
MVCh2200 & 320 \\
\hline
\end{tabular}




\subsection{Material properties and initial field stress conditions}

The in situ material types encountered at the MVF mine site includes clayey and sandy overburden material overlying Yallourn coal seam, which overlies the clayey Yallourn interseam. The clay interseams strength is known to be inherently variable. In addition to in situ material overburden dump material used for backfilling (Township Field) and engineered clay fill used in the construction of the MRD are present at the MVF site (Figure 7).

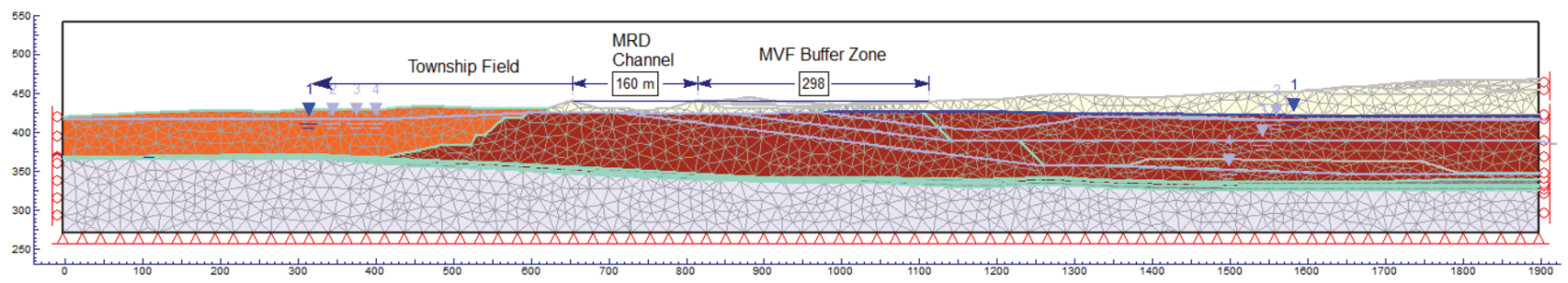

\begin{tabular}{|c|c|c|c|c|c|c|}
\hline Material & Y1 Coal & Y2 Coal & Overburden & $\begin{array}{c}\text { Weak / Sheared } \\
\text { Interseam }\end{array}$ & Interseam & $\begin{array}{c}\text { Natural } \\
\text { Overburden }\end{array}$ \\
\hline Material Colour & $\square$ & $\square$ & $\square$ & & $\square$ \\
\hline
\end{tabular}

Figure 7 Cross-section of the Yallourn Open Cut

The model mesh was assigned using graded three-noded triangles, where 'poor quality' mesh elements are defined by:

- Side length ratio (maximum/minimum) $>30$.

- Minimum interior angle $<2^{\circ}$.

- Maximum interior angle $>175^{\circ}$.

The density of the mesh was refined through geometry clean up and/or alteration of the geometry until the mesh quality model had $<0.1 \%$ 'bad' elements. On average, mesh element lengths were in the order of $5 \mathrm{~m}$.

The material strength and stiffness properties used to undertake the preliminary iterations were sourced from prior studies at the site as summarised in Table 2.

Table 2 Summary of material parameters

\begin{tabular}{|c|c|c|c|c|c|}
\hline \multirow[b]{2}{*}{ Material type } & \multicolumn{2}{|c|}{ Initial stiffness parameters } & \multicolumn{3}{|c|}{ Strength parameters } \\
\hline & $\begin{array}{l}\text { Young's modulus } \\
\text { (MPa) }\end{array}$ & $\begin{array}{l}\text { Poisson's } \\
\text { ratio }\end{array}$ & $\begin{array}{l}\text { Tensile strength } \\
\text { (MPa) }\end{array}$ & $\begin{array}{l}\text { Friction angle } \\
\text { (peak) }\left({ }^{\circ}\right)\end{array}$ & $\begin{array}{l}\text { Cohesion } \\
\text { (peak) (MPa) }\end{array}$ \\
\hline $\begin{array}{l}\text { Natural } \\
\text { overburden clay }\end{array}$ & 40 & 0.30 & 0.000 & 28 & 0.02 \\
\hline Yallourn coal & 40 & 0.27 & 0.150 & 30 & 0.15 \\
\hline Interseam clay & 65 & 0.3 & 0.025 & 25 & 0.025 \\
\hline $\begin{array}{l}\text { Weak/sheared } \\
\text { interseam }\end{array}$ & 40 & 0.3 & 0.000 & 16 & 0.003 \\
\hline $\begin{array}{l}\text { Overburden } \\
\text { dump }\end{array}$ & 15 & 0.3 & 0.000 & 25 & 0.002 \\
\hline
\end{tabular}

Initial field stress conditions, as outlined in Table 3, were attributed based on the regional tectonic setting, noting that the subject area was sitting a stress relieved 'halo'. 
Table 3 Summary of initial field stress conditions

\begin{tabular}{lll}
\hline Filed Stress $-K_{0}$ & \multicolumn{1}{l}{ Minimum } & Maximum \\
\cline { 2 - 3 } & 0.4 & 1.2 \\
\hline
\end{tabular}

\subsection{Groundwater profile}

It well understood that ground movement and stability of the brown coal mine batters are sensitive to groundwater profiles, i.e. horizontal movement is sensitive to the modelled hydraulic gradient within. The groundwater profile within the study area was interpreted using a series of existing observational bores. The interpreted hydraulic gradients corresponding to each of the stability sections are summarised below in Table 4.

Table 4 Summary of interpreted hydraulic gradients

\begin{tabular}{ll}
\hline Section & Hydraulic gradient (degrees) \\
\hline MVCh1700 & 5.7 \\
MVCh1800 & 5.8 \\
MVCh2000 & 4.8 \\
MVCh2200 & 7.0 \\
\hline
\end{tabular}

\subsection{Geological structure/joints}

The ubiquitous joints function was utilised to define the presence of coal joints within the coal seam/s. This function enables the implicit accounting for jointing in coal. The Ubiquitous Joint function was chosen for its ability to provide flexibility in defining critical deformation/slip planes, which could be readily attributed to observations in monitoring instruments, e.g. shear movements in inclinometers. Given that coal joints occur ubiquitously and in all directions, coal joint properties were implicitly accounted for in the coal stiffness properties outlined in Table 2.

\subsection{Model calibration}

When considering the approach to calibration of the FEM model, the authors focused on initially 'matching' predicted horizontal displacements with the magnitudes of the maximum horizontal surface and subsurface displacements observed through monitoring data. Horizontal movements were matched through iteratively refining the stiffness parameters of the various geological units and field stress conditions. Pore pressures within the coal unit were modelled using a hydraulic gradient that was reflective of the long-term groundwater behaviour for the area. Upon reaching a satisfactory correlation between predicted and observed horizontal movement, the model was further refined until vertical surface and subsurface movements were also matched, and when the final model outcomes were considered to be representative within a reasonable tolerance to the overall deformation trends noted from the geotechnical instrumentation (Figure 8). 


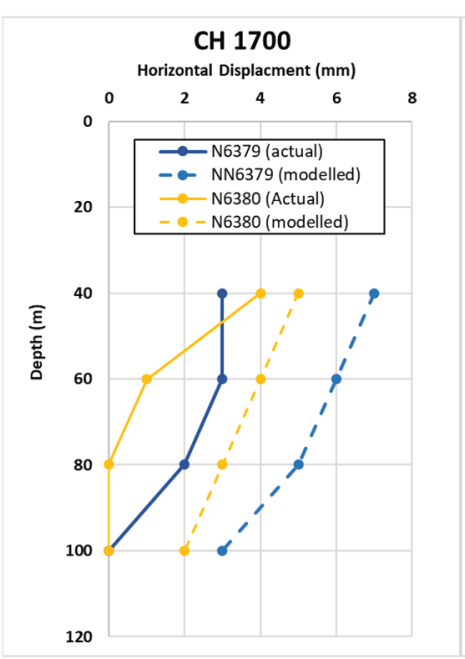

(a)

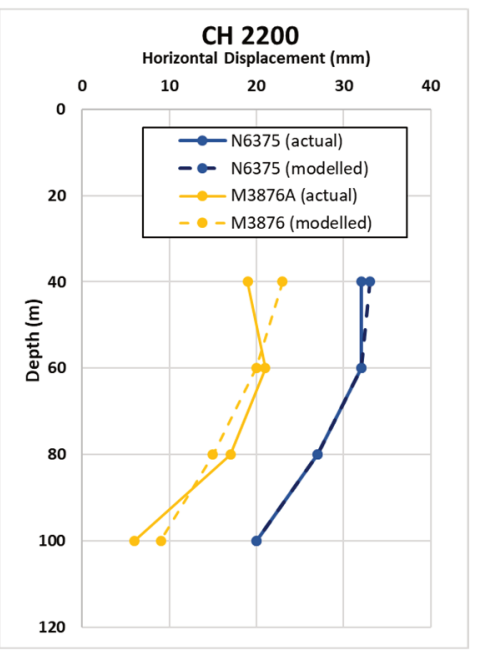

(b)

Figure 8 Monitored versus modelled (calibrated) horizontal displacement at depths 40, 60, 80 and 100 m; (a) MVCh1700; (b) MVCh2200

\subsubsection{Model staging}

In model calibration, it is necessary to stage the sequence of development to ensure that observed/measured slope deformation response(s) are adequately attributed. This is a crucial component in ensuring the efficacy of the models predictive capability. When staged developments are not considered there is potential for predictions of deformation to be over-estimated. The process of staging allows aspects such as horizontal movement to be accurately correlated with monitoring data for specific time domains.

\subsubsection{Data reduction}

Ground movement monitoring data was obtained and reviewed for each of the stability section. Graphical data was digitised and reduced in a spreadsheet to correlate surface and subsurface deformation magnitudes (Figure 9) to the chronology of mine development (Figure 10). As an example, the development chronology along stability section MVCh2200 is shown for the period December 2015 to October 2018 below in Figure 10 along with the magnitudes of horizontal movement sustained.

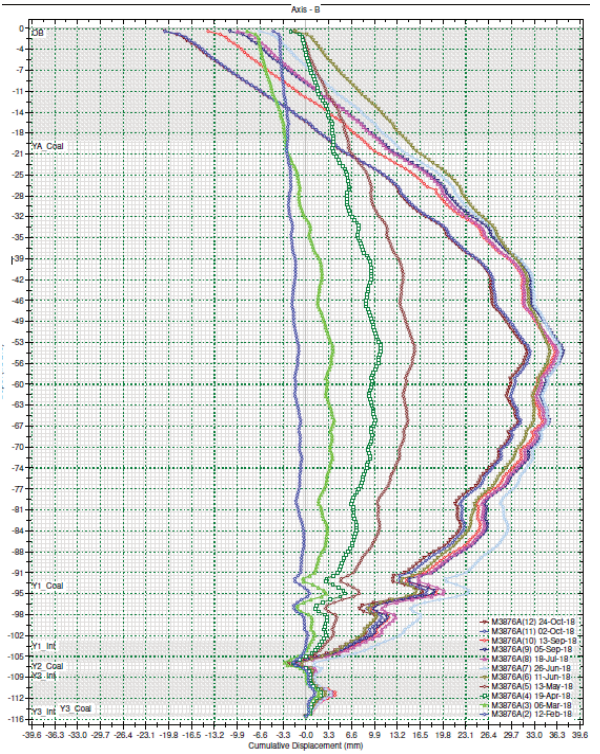

(a)

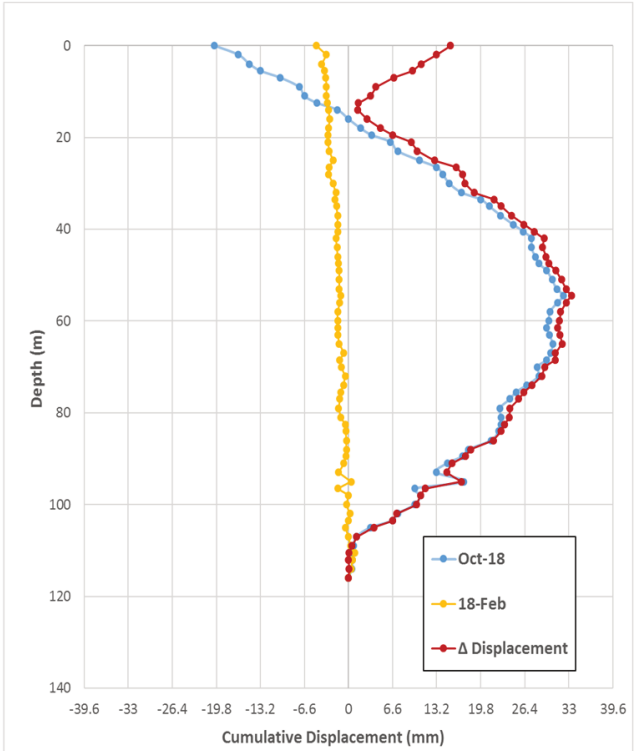

(b)

Figure 9 Inclinometer data reduction: (a) field inclinometer data; (b) reduced inclinometer data 


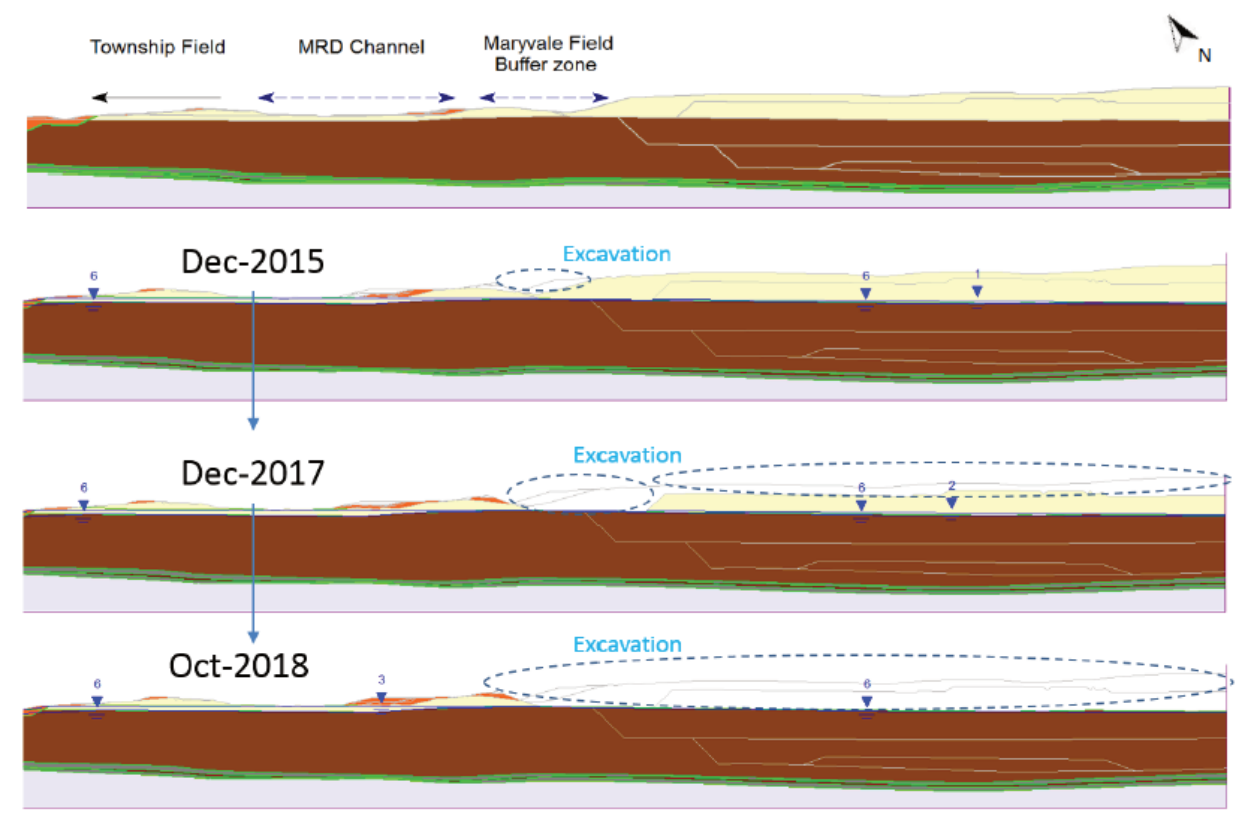

Figure 10 Development chronology: MVCh2200

\subsubsection{Mesh creation and refinement}

The accuracy to which a FEM model can be integrated is directly related to the suitability of the finite element mesh (Bathe \& Zhang 2017). The mesh subdivides the overall model, which are independently subjected to calculation algorithms to evaluate stress and strain. A number of considerations with respect to the mesh refinement process were made owing to the complexities associated with the geometry of the geological model and mine development. Accordingly, an iterative process was employed and was undertaken by the authors as follows:

1. An initial computation phase was undertaken on a comparatively 'coarse' mesh.

2. Refinement of the mesh in key areas, i.e. along the interseam contact.

3. Removal of superfluous nodes and add nodes to improve the mesh quality, i.e. removal of irregular mesh elements.

4. Successive model computation phases incorporated progressively finer meshes and the results between these different meshes were compared.

5. Repeat Step 4 until the changes between successive models became negligible as this indicates optimal meshing outcomes.

\subsubsection{Calibration process}

Using reduced geotechnical data, the input parameters Young's modulus (E), Poisson's ratio (v) and the in situ field stress ratio $\left(\mathrm{K}_{0}\right)$ were iteratively altered until the predicted magnitude of horizontal displacement was within a tolerable range of the actual recorded horizontal displacement. For the purpose of explanation, the process involved in the calibration of MVCh2200 is described as follows:

1. Initial model inputs were sourced from the 2008 models.

2. The model was run with initial input parameters, which did not replicate the measured displacements, hence the process of iterative parameter variation was performed, as depicted in Figure 11.

3. Step 2 was repeated until the measured displacements were replicated in the models at the respective depth intervals. The iterative calibration resulted in model predictions that were within 
$4 \mathrm{~mm}$ of the measured displacement (Table 5). It should be noted that the results of the calibration are outlined for the current mine state (year 2018), and have accounted for mine developments commencing in 2015.

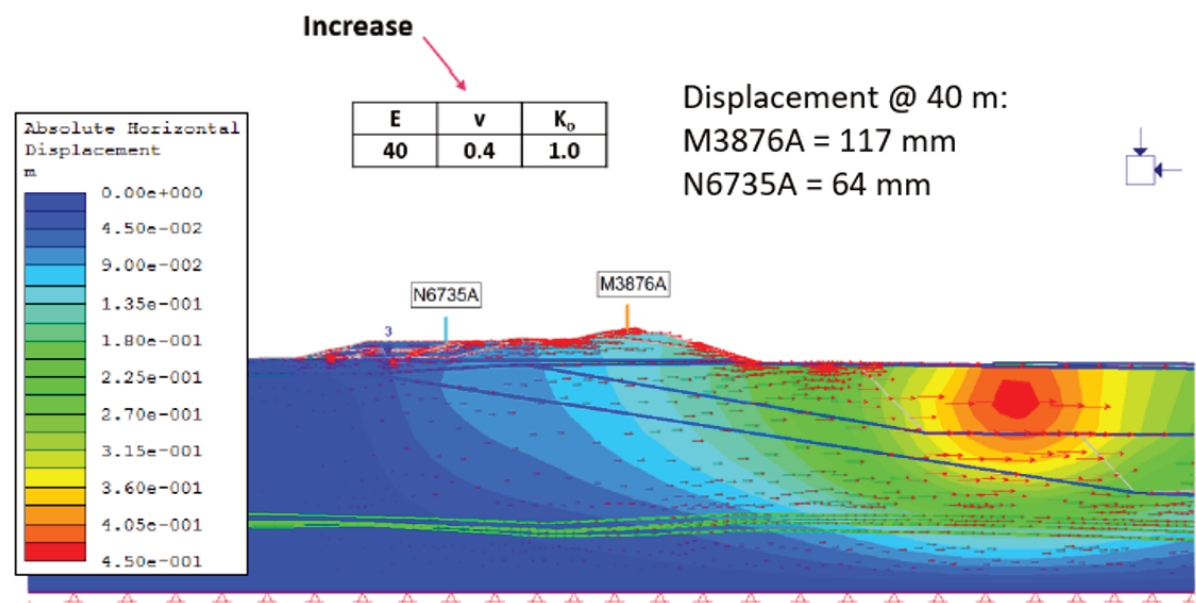

(a)

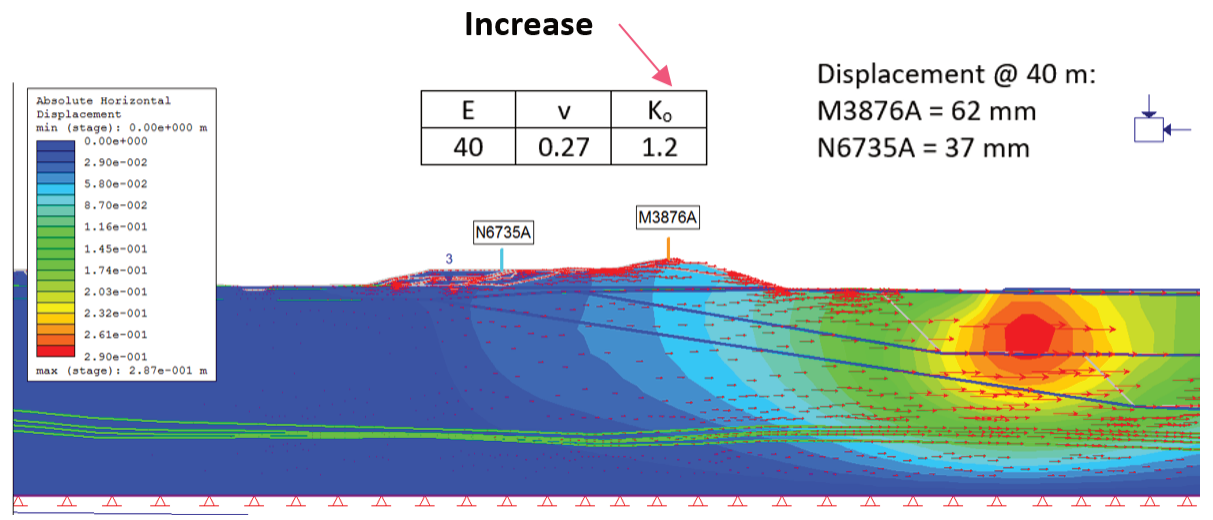

(b)

Figure 11 Horizontal displacement when (a) Poisson's ratio is increased from 0.27 to 0.4 and (b) field stress is increased from 1.0 to 1.2

Table 5 Calibration outcomes for stability section MVCh2200

\begin{tabular}{llll}
\hline Depth $(\mathbf{m})$ & $\begin{array}{l}\text { Inclinometer } \\
\text { displacement }(\mathrm{mm})\end{array}$ & $\begin{array}{l}\text { Predicted } \\
\text { displacement }(\mathbf{m m})\end{array}$ & $\begin{array}{l}\Delta \text { displacement } \\
(\mathbf{m m})\end{array}$ \\
\hline 40 & 32 & 33 & 1 \\
60 & 32 & 32 & 0 \\
80 & 27 & 29 & 2 \\
100 & 20 & 21 & 1 \\
40 & 19 & 23 & 4 \\
60 & 21 & 20 & 1 \\
80 & 17 & 15 & 2 \\
100 & 6 & 9 & 3 \\
\hline
\end{tabular}


The material calibration outcomes from Step 3 were utilised as the new initial input parameters into the MVCh1700 model and the above-outlined process was repeated. The inputs derived for MVCh1700 were applied to the original MVCh2200 calibration model to ensure that the difference in horizontal displacements remained within a tolerable range. Once MVCh2200 and MVCH1700 were calibrated the model inputs were subsequently used to for the remaining sections, i.e. MVCh1800 and MVCh2000 and the calibration outcomes were further refined.

Tabulated below in Tables 6 and 7 are the calibrated model parameters as calibrated by the authors in comparison to conceptual 2008 inputs.

Table 6 Calibrated stiffness parameters used in finite element model modelling compared to initial stiffness parameters

\begin{tabular}{|c|c|c|c|c|}
\hline \multirow{2}{*}{$\begin{array}{l}\text { Material } \\
\text { parameter }\end{array}$} & \multicolumn{2}{|l|}{ Initial (2008) } & \multicolumn{2}{|l|}{ Calibrated (2019) } \\
\hline & $\begin{array}{l}\text { Young's modulus } \\
-E(\mathrm{MPa})\end{array}$ & $\begin{array}{l}\text { Poisson's } \\
\text { ratio }(v)\end{array}$ & $\begin{array}{l}\text { Young's modulus } \\
-E(\mathrm{MPa})\end{array}$ & $\begin{array}{l}\text { Poisson's } \\
\text { ratio (v) }\end{array}$ \\
\hline $\begin{array}{l}\text { Natural } \\
\text { overburden }\end{array}$ & 40 & 0.30 & 38 & 0.27 \\
\hline Yallourn coal & 40 & 0.27 & 35 & 0.23 \\
\hline Interseam & 65 & 0.30 & 58 & 0.28 \\
\hline Weak interseam & 40 & 0.30 & 28 & 0.25 \\
\hline
\end{tabular}

Table 7 Calibrated field stress parameter compared to initial field stress

\begin{tabular}{lllll}
\hline \multirow{2}{*}{ Parameter } & \multicolumn{2}{l}{ Initial (2008) } & \multicolumn{2}{l}{ Calibrated (2019) } \\
\cline { 2 - 5 } & Minimum & Maximum & Minimum & Maximum \\
\hline Field stress $\left(K_{0}\right)$ & 0.4 & 1.2 & 0.6 & 1.0 \\
\hline
\end{tabular}

Owing to the above calibration findings, a redundancy check was undertaken using a network of extensometers located at the Morwell River and the MRD to further validate the calibration results (Table 8).

Table 8 Redundancy check using virtual extensometers located within the Morwell River Diversion

\begin{tabular}{lll}
\hline $\begin{array}{l}\text { Stability } \\
\text { section }\end{array}$ & $\begin{array}{l}\text { Measured horizontal } \\
\text { displacement }(\mathbf{m m})\end{array}$ & $\begin{array}{l}\text { Predicted horizontal } \\
\text { displacement }(\mathbf{m m})\end{array}$ \\
\hline MVCh1800 & 3.0 & 4.0 \\
& $12.5^{*}$ & $8.0^{*}$ \\
MVCh2200 & 12.0 & 12.5 \\
\hline
\end{tabular}

The above check provided additional confidence that the predictive capability of the calibrated model would provide results within an acceptable tolerance, and implicitly accounts for past development history and stress relief.

\section{$4 \quad$ Life-of-mine: predictive modelling}

Using the calibrated FEM model, predictive ground movement modelling was undertaken on the MVF-MRD buffer zone considering the proposed final life of the mine, i.e. the 2032 design. The results of the predictive 
modelling were used to assess the maximum horizontal ground movement for the vertical development of the mine, specifically two stages as follows:

- Excavation of the upper coal cut to the first bench (M300 level $\approx \mathrm{RL}-5 \mathrm{~m}$ AHD).

- Including the removal of overburden above the top of coal (M100 level $\approx R L+32 \mathrm{~m} \mathrm{AHD)}$.

- The placement of grass level surcharge.

- Excavation of the lower coal cut to the mine floor (M400 level $\approx \mathrm{RL}-47 \mathrm{~m}$ AHD).

- Placement of floor surcharge (internal overburden dump), which has been designed to aid in 'weight balance' on the final pit floor to mitigate the potential for floor heave as a result of aquifer pressure.

The sequential development of the MVF open cut is shown using a series of schematics (Figure 12).

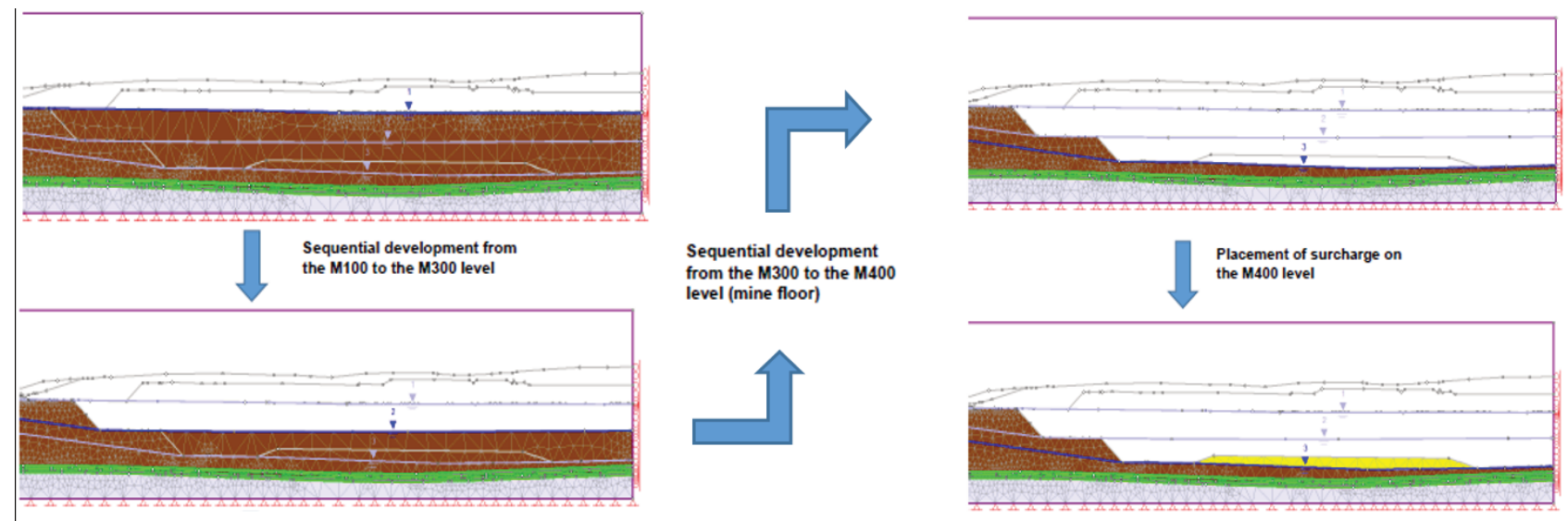

Figure 12 Sequential development of the Yallourn Open Cut Maryvale Field

\subsection{Modelled horizontal displacements}

Horizontal ground movements were interpreted across the Morwell River Flood Plain and MRD through to the crest of the mine across the four stability sections. Ground movements were modelled at the crest of the mine batters and at the MRD, the results of which are summarised below in Table 9.

Table 9 Maximum horizontal ground displacements Maryvale Field-Morwell River Diversion

\begin{tabular}{lllll}
\hline \multirow{2}{*}{ Location } & \multicolumn{2}{l}{$\begin{array}{l}\text { Morwell River/Morwell River } \\
\text { Diversion flood plain }\end{array}$} & \multicolumn{2}{l}{ Crest of mine batter } \\
\cline { 2 - 5 } & $\begin{array}{l}\text { Excavation of } \\
\text { upper coal cut } \\
\text { (M300) }\end{array}$ & $\begin{array}{l}\text { Excavation of } \\
\text { lower coal cut } \\
\text { (M400) }\end{array}$ & $\begin{array}{l}\text { Excavation of } \\
\text { upper coal cut } \\
\text { (M300) }\end{array}$ & $\begin{array}{l}\text { Excavation of } \\
\text { lower coal cut } \\
\text { (M400) }\end{array}$ \\
\hline MVCh1700 & 129 & 214 & 214 & 569 \\
MVCh1800 & 101 & 146 & 234 & 690 \\
MVCh2000 & 134 & 345 & 171 & 453 \\
MVCh2200 & 56 & 133 & 254 & 471 \\
\hline
\end{tabular}

Note: Horizontal movements in millimetres

These predictively modelled scenarios now provide a basis for the mine to proactively monitor movement and create management protocols and further model refinements as mine development continues over the ensuing period. 


\subsection{Sensitivity scenarios considered}

In addition to predictive modelling of the proposed life-of-mine design, the authors also considered a number of serious loading (i.e. flood event) scenarios within the MRD, which are outlined below in Table 10.

Table 10 Effect of Morwell River and Morwell River Diversion flooding to RL $43 \mathrm{~m}$ AHD on horizontal displacement

\begin{tabular}{lll}
\hline Development stage & MVCh2000 & MVCh2200 \\
\hline M300 & $181(134)$ & $123(56)$ \\
M400 & $359(345)$ & $214(133)$ \\
\hline Note: () - Maximum horizontal ground movement under river base flow conditions
\end{tabular}

These sensitivity assessments provide the mine with added certainty around management protocols during significant flood flows.

\section{Conclusion}

This case study demonstrates how the authors were able to formulate and calibrate a finite element model in a site that has had a significant history of development. The approach employed resulted in a predictive model that can be proactively used by the mine to measure and manage their rate of development in the light of challenging geological conditions. It also provides a firm basis for undertaking further assessments such as shear reduction factors and the effects of groundwater fluctuations.

\section{Acknowledgements}

The authors thank Energy Australia Yallourn for providing the opportunity to publish this paper and GHD for providing the necessary resources. In particular, the authors would like to give thanks to Mr Lance Wallace, Mr Doug Hibberd, Mr Gordon Bakker and Mr Ron Mether (EnergyAustralia Yallourn) for their insight and guidance during the planning and execution of this work. Additionally, the authors give thanks to Mr Slavko Kacavenda and Mr Dave Clark of GHD Pty Ltd for their technical guidance and expertise during the course of this project.

\section{References}

Abrahamsson, T \& Kammer, DC 2015, 'Finite element model calibration using frequency responses with dampening equalization', Mechanical Systems and Signal Processing, vol. 62, pp. 218-234.

Bathe, KJ \& Zhang, L 2017, 'The finite element method with overlapping elements - a new paradigm for CAD driven simulations, Computers and Structure, vol. 182, pp. 526-539.

Government of Victoria 2008, Yallourn mine batter failure inquiry: government response, Department of Primary Industries, Victorian Government Printer, Parliamentary paper no. 2006-10, no. 158, pp. 1-131.

Narendranathan, S \& Cheng, M 2019, 'Development of the Mine Geotechnical Risk Index', in J Wesseloo (ed.), Proceedings of the First International Conference for Mining Geomechanics Risk Conference, Australian Centre for Geomechanics, Perth, pp. 461-474. 